\title{
LATE COMPLICATIONS OF EXTRAPERIOSTEAL LUCITE BALL PLOMBAGE
}

\author{
BY \\ M. FEUCHTWANGER, J. B. BORMAN, AND I. BRUDERMAN \\ From the Department of Chest Surgery, Rothschild-Hadassah University Hospital, Jerusalem, Israel
}

(RECEIVED FOR PUBlication NOVEMBER 31, 1960)

Extraperiosteal plombage with lucite balls is well established as an effective procedure in the surgical treatment of far-advanced pulmonary tuberculosis, particularly when more extensive or resective surgery is contraindicated (Lucas and Cleland, 1950; Wilson, Armada, Vindzberg, and O'Brien, 1956 ; Young, 1958). Originally, this operation was done in two stages, the first entailing insertion of the spheres, and the second removal of the plomb and conversion to thoracoplasty (Woods, Walker, and Schmidt, 1950). The time that elapsed between the two operations varied between three and six months. However, following the favourable reports of Woods and Buente (1953) and Wilson, Armada, O'Brien, and Vindzberg (1955), we decided to omit the second stage in 1955. Our decision was influenced by the clean, uninfected plombage spaces which we found in our first 21 patients, in whom conversion thoracoplasty was routinely done three to four months after insertion of the plomb. In a previous report from this service (Milwidsky and Romanoff, 1956) the early follow-up of patients so treated did not reveal complications and we felt justified in continuing with a one-stage operation. To date, 100 planned one-stage extraperiosteal plombages with lucite balls have been done in our service. However, during the last two years an increasing number of these patients have presented themselves with complications due to the presence of the plomb. This paper summarizes the reports on 18 such patients, two of whom had bilateral space infections (Table I).

\section{COMMENT}

Before the plomb was inserted all patients received prolonged antituberculous therapy, including drug treatment, for a period ranging from one to eight years.
All patients were sputum positive at the time of the first operation.

With one exception, the disease was bilateral in all cases.

In no case was apicolysis done.

Every patient continued to receive conservative therapy after the first-stage operation.

\section{Discussion}

One hundred planned one-stage extraperiosteal plombage procedures were done in 98 patients, two of whom had bilateral operations. Eighteen patients (including the two who had had the bilateral operation) presented themselves for further surgical treatment because of complications due to the retained plomb. The incidence of complications at present is $20 \%$. We feel that it is probable that had we been able to follow up all our cases an even higher rate of complications would have been found.

Young's (1958) finding that adequate preoperative antimicrobial treatment prevented space infections is not borne out by our experience. All our patients received prolonged antituberculous therapy for a minimum of one year and often for many years. Despite this our complication rate is $20 \%$ compared with Young's $2 \frac{1}{2} \%$ in those of his patients who had had adequate drug treatment.

We agree with Wilson et al. (1956) that apicolysis should not be attempted in these operations, as it may predispose to infection of the extraperiosteal space. However, omitting apicolysis does not safeguard against later complications which are apparently caused by the presence of the foreign body and the continuous pressure it exerts on the denuded ribs.

There is considerable difference of opinion as to the time interval that should elapse between insertion of the plomb and the manifestation of 
TABLE I

RESULTS IN 18 PATIENTS SUBJECTED TO PLOMBAGE WITH LUCITE BALLS

\begin{tabular}{|c|c|c|c|c|}
\hline $\begin{array}{l}\text { Case } \\
\text { No. }\end{array}$ & $\begin{array}{c}\text { Name, } \\
\text { Age, } \\
\text { Sex }\end{array}$ & \begin{tabular}{|c|} 
Time \\
Interval \\
between \\
Two \\
Operations \\
(Months)
\end{tabular} & $\begin{array}{c}\text { Clinical } \\
\text { Presentation } \\
\text { of } \\
\text { Complications }\end{array}$ & $\begin{array}{l}\text { Findings } \\
\text { at } \\
\text { Second } \\
\text { Operation }\end{array}$ \\
\hline 1 & $\underset{57 \mathrm{~F}}{\text { H.G.S. }}$ & 41 & $\begin{array}{l}\text { Fluctuant mass, } \\
\text { fever, cough }\end{array}$ & $\begin{array}{l}\text { Giant cold abscess, } \\
\text { rib necrosis }\end{array}$ \\
\hline 2 & $\begin{array}{l}\text { R.M. } \\
38 \mathrm{M}\end{array}$ & 24 & $\begin{array}{l}\text { Symptom free (re- } \\
\text { admitted because } \\
\text { of non-collapsed } \\
\text { cavity underneath } \\
\text { plomb) }\end{array}$ & $\begin{array}{l}\text { Cracked balls, } \\
\text { fractured ribs }\end{array}$ \\
\hline 3 & A.S.S. & 18 & $\begin{array}{l}\text { Intractable pain at } \\
\text { site of operation }\end{array}$ & $\begin{array}{l}\text { Cold abscess, frac- } \\
\text { tured ribs }\end{array}$ \\
\hline 4 & $\begin{array}{l}\text { F.H. } \\
48 \mathrm{M}\end{array}$ & 16 & $\begin{array}{l}\text { Fluctuant mass } \\
\text { under scar, pain }\end{array}$ & \\
\hline 5 & $\begin{array}{l}\text { I.H. } \\
30 \mathrm{~F}\end{array}$ & 19 & Discharging sinus & $\begin{array}{l}\text { Cold abscess, nec- } \\
\text { rotic fractured } \\
\text { ribs }\end{array}$ \\
\hline 6 & $\begin{array}{l}\text { S.I. } \\
55\end{array}$ & 15 & $\begin{array}{l}\text { Symptom free, frac- } \\
\text { tured ribs and } \\
\text { migrated ball } \\
\text { detected } \\
\text { radiologically }\end{array}$ & $\begin{array}{l}\text { Ball in medias- } \\
\text { tinum, fractured } \\
\text { ribs, cracked } \\
\text { balls }\end{array}$ \\
\hline 7 & $\begin{array}{l}\text { M.M. } \\
35 \text { F }\end{array}$ & 28 & $\begin{array}{l}\text { Haemoptysis, fever, } \\
\text { fluctuant mass, } \\
\text { pain }\end{array}$ & $\begin{array}{l}\text { Cold abscess, frac- } \\
\text { tured ribs, bron- } \\
\text { cho-extraperi- } \\
\text { osteal space } \\
\text { communication }\end{array}$ \\
\hline 8 & $\begin{array}{l}\text { T.M. } \\
48 \mathrm{~F}\end{array}$ & 14 & $\begin{array}{l}\text { Discharging sinus, } \\
\text { fever }\end{array}$ & $\begin{array}{l}\text { Cold abscess, nec- } \\
\text { rosis of ribs }\end{array}$ \\
\hline 9 & F.A. & 18 & Mass under scar & $\begin{array}{l}\text { Cold abscess, frac- } \\
\text { tured ribs }\end{array}$ \\
\hline 10 & $\begin{array}{l}\text { A.M. } \\
59 \mathrm{M}\end{array}$ & 42 & , , , , & $\begin{array}{l}\text { Cold abscess, } \\
\text { cracked balls, } \\
\text { fractured ribs }\end{array}$ \\
\hline 11 & $\begin{array}{l}\text { B.A. } † \\
34 \mathrm{M}\end{array}$ & 29 & $\begin{array}{l}\text { Deterioration in } \\
\text { general condition, } \\
\text { non-collapsed } \\
\text { cavity underneath } \\
\text { plomb }\end{array}$ & $\begin{array}{l}\text { Ball in medias- } \\
\text { tinum, cracked } \\
\text { spheres, space } \\
\text { infection }\end{array}$ \\
\hline 12 & $\begin{array}{l}\text { A.A. } \\
32 \text { F }\end{array}$ & 14 & $\begin{array}{l}\text { Mass under scar, } \\
\text { pain, fever }\end{array}$ & $\begin{array}{l}\text { Cold abscess, nec- } \\
\text { rosis of ribs }\end{array}$ \\
\hline 13 & $\underset{57 \mathrm{M}}{\mathrm{K} . \mathrm{Y}}$ & 13 & $\begin{array}{l}\text { Symptom free, spu- } \\
\text { tum not converted, } \\
\text { persistent cavity }\end{array}$ & $\begin{array}{l}\text { Necrotic fractured } \\
\text { ribs }\end{array}$ \\
\hline 14 & $\begin{array}{l}\text { S.M. } \\
41 \mathrm{M}\end{array}$ & 40 & $\begin{array}{l}\text { Haemoptysis and } \\
\text { non-conversion of } \\
\text { sputum, fractured } \\
\text { ribs detected } \\
\text { radiologically }\end{array}$ & ", \\
\hline 15 & $\begin{array}{l}\text { P.B. } \\
27 \text { M }\end{array}$ & 54 & $\begin{array}{l}\text { Symptom free, frac- } \\
\text { tured ribs and } \\
\text { fluid levels detec- } \\
\text { ted radiologically }\end{array}$ & $"$, \\
\hline $16 a$ & $\begin{array}{l}\text { S.Z. } \\
47 \text { M }\end{array}$ & 46 & $\begin{array}{l}\text { Right side, cold } \\
\text { abscess and pain }\end{array}$ & $\begin{array}{l}\text { Cold abscess, frac- } \\
\text { tured ribs }\end{array}$ \\
\hline $16 b$ & $\begin{array}{l}\text { S.Z. } \\
47 \mathrm{M}\end{array}$ & 48 & $\begin{array}{l}\text { Left side, cold } \\
\text { abscess, pain }\end{array}$ & $\begin{array}{l}\text { Cold abscess with } \\
\text { spread of infec- } \\
\text { tion to axillary } \\
\text { and paravertebral } \\
\text { areas, fractured } \\
\text { necrotic ribs }\end{array}$ \\
\hline $17 \mathrm{a}$ & $\begin{array}{l}\text { P.A. } \\
59 \text { M }\end{array}$ & 50 & $\begin{array}{c}\text { General feeling of } \\
\text { malaise, right side, } \\
\text { fractured ribs and } \\
\text { fluid levels detec- } \\
\text { ted radiologically }\end{array}$ & $\begin{array}{l}\text { Fractured necrotic } \\
\text { ribs, space infec- } \\
\text { tion }\end{array}$ \\
\hline $17 b$ & $\begin{array}{l}\text { P.A. } \\
59 \text { M }\end{array}$ & 44 & Left side, ditto & , \\
\hline 18 & $\underset{33}{\mathbf{M}} \mathbf{M}$ & 48 & $\begin{array}{c}\text { Pain, fractured ribs } \\
\text { and fluid levels } \\
\text { detected radio- } \\
\text { logically }\end{array}$ & ", \\
\hline
\end{tabular}

* At time of second operation.

$\uparrow$ Died one month after pneumonectomy done at time of conversion operation. complications. Cleland (1956) reported that most infections occurred within two years of operation. Macarthur (1957), on the other hand, stated that the clinical evidence of infection in the extraperiosteal space occurred after about three years. Our patients presented themselves between 11 months and four years after operation. We therefore assume that there is no set time limit for the appearance of complications.

The most common presenting feature in this series was a fluctuant mass beneath the scar which occurred in eight instances. Six patients, one with bilateral plomb, complained of pain in the region of the operation. Four had fever. Two presented with sinuses from cold abscesses which had ruptured. Five patients were symptom-free, but were readmitted because their sputum had not converted or because routine follow-up radiographs had shown pathological fractures of the ribs.

At operation, the fluctuant masses were found to be cold abscesses (Table I). All patients had avascular necrosis of the ribs. In many extraperiosteal spaces the balls had cracked and contained infected material. In four a ball had migrated either to the axilla or to the mediastinum. In one patient a ball had eroded the underlying lung, causing a broncho-extraperiosteal communication. This was the only patient who developed wound infection following removal of the plomb. One patient, who had bilateral cold abscesses, was found to have tuberculous spread from both extraperiosteal spaces to the axillary and paravertebral areas. He responded very well to bilateral conversion thoracoplasty supplemented by intensive drug therapy. A patient whose sputum was positive due to a large cavity beneath the infected plomb, and in whom pneumonectomy was done at the time of removal of the plomb, succumbed one month after operation because of empyema (Case 11).

When converting to a thoracoplasty we did not find it necessary to remove the first rib as advocated by Macarthur (1957). Except for the patient mentioned above who died, all patients improved after the conversion operation. The post-operative morbidity was low and the wounds healed by first intention.

It is not the aim of this paper to discuss the results of extraperiosteal plombage as regards the underlying lung pathology. However, it should be mentioned that three of these 18 patients must be regarded as failures of collapse therapy, since residual cavities could be demonstrated radiologically beneath the plomb. These three patients 
remained sputum positive. Of the remaining 15 patients sputum conversion was achieved in five. The other 10 patients were intermittently positive. All these had bilateral, far-advanced disease, so that the source of the positive sputum may have been the contralateral lung.

\section{SUMMARY}

Of 100 planned one-stage plombage operations for advanced pulmonary cavitary tuberculosis, $20 \%$ presented with late complications necessitating removal of the plomb and "conversion thoracoplasty."

The main complications were space infections and avascular necrosis of the ribs.

In view of these findings we recommend abandoning the planned one-stage procedure and reverting to elective "conversion thoracoplasty" three to six months after insertion of the plomb.

We wish to express our thanks to Professor $\mathbf{H}$. Milwidsky, at whose instigation this study was undertaken, for his helpful criticism and advice.

\section{REFERENCES}

Cleland, W. P. (1956). J. thorac. Surg., 32, 813.

Lucas, B. G. B., and Cleland, W. P. (1950). Thorax, 5, 248.

Macarthur, A. M. (1957). Ibid., 12, 338.

Milwidsky, H., and Romanoff, H. (1956). Brit. J. Tuberc., 50, 301.

Wilson, N. J., Armada, O., O'Brien, W. B., and Vindzberg, W. V. (1955). Amer. J. Surg., 89, 663. Surg., 32, 797 .

Woods, F. M., and Buente, L. (1953). Amer. Rev. Tuberc., 68, 902. - Walker, J. H., and Schmidt, I. (1950). Dis. Chest, 18, 401.

Young, F. H. (1958). Thorax, 13, 130. 